\title{
Assessment of absorbing aerosols on austral spring snow albedo reduction by several basins in the Central Andes of Chile from daily satellite observations (2000-2016) and a case study with the WRF-Chem model
}

\author{
Tomás Rafael Bolaño-Ortiz ${ }^{1,2}$ (1) $\cdot$ Romina María Pascual-Flores ${ }^{1,2}$ - Ana Isabel López-Noreña ${ }^{1,2}(\mathbb{D}$.

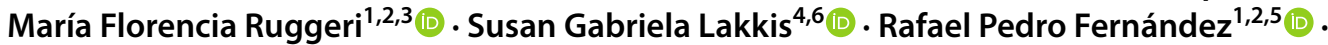 \\ Salvador Enrique Puliafito ${ }^{1,2}$ (B)
}

(c) Springer Nature Switzerland AG 2019

\begin{abstract}
Changes in snow albedo (SA) on the Limari, Choapá, Aconcagua and Maipo basins of the Central Andes of Chile (CAC) are associated with the possible deposition of light-absorbing particles in the austral spring. We correlate SA with daily data of snow cover, aerosol optical depth (AOD) and land surface temperature (LST) available from the Moderate Resolution Imaging Spectroradiometer (MODIS) onboard the NASA Terra satellite between 2000 and 2016, and other derived parameters such as days after albedo (DAS) and snow precipitation (SP). We used satellite pixels with $100 \%$ snow cover to obtain monthly average value of SA, LST, AOD, DAS and SP from September to November performing multiple regression analysis. We show that in Maipo, after considering LST, AOD represents an important role in changes induced to SA. The multiple regression model illustrates that AOD increases can reduce the SA during spring months by $13.59,0.01,0.77$ and 3.8\% in Limari, Choapá, Aconcagua and Maipo, respectively. In addition, we used a numerical prediction Weather Research and Forecasting model coupled with Chemistry (WRF-Chem), showing that the black carbon distribution and average daily AOD are associated with the SA decrease of 0.15 in the Maipo basin between September 29 and 30, 2016. The WRF-Chem output showed aerosols are transported mainly with dominating westerly winds to the Limari and Maipo basins. Our results further suggest that SA decrease due to AOD may be originated in the largest industrial and urban areas in Chile, producing a negative impact on the hydrological resource, generated in the CAC.
\end{abstract}

Keywords Snow albedo $\cdot$ MODIS · AOD · Snow darkening effect · WRF-Chem · Central Andes in Chile

Electronic supplementary material The online version of this article (https://doi.org/10.1007/s42452-019-1256-z) contains supplementary material, which is available to authorized users.

Tomás Rafael Bolaño-Ortiz, tomas.bolano@frm.utn.edu.ar | 'GEAA - Grupo de Estudios Atmosféricos y Ambientales, UTN-FRM - Universidad Tecnológica Nacional - Facultad Regional Mendoza, Mendoza, Argentina. ${ }^{2}$ CONICET - Consejo Nacional de Investigaciones Científicas y Técnicas, Buenos Aires, Argentina. ${ }^{3}$ CETAM- UMS - Centro de Tecnologías Ambientales, Universidad Técnica Federico Santa María, Valparaíso, Chile. ${ }^{4} \mathrm{FICA}$ - UCA - Facultad de Ingeniería y Ciencias Agrarias, Pontificia Universidad Católica Argentina, Buenos Aires, Argentina. ${ }^{5}$ FCEN-UNCUYO - Facultad de Ciencias Exactas y Naturales, Universidad Nacional de Cuyo, Mendoza, Argentina. ${ }^{6}$ UTN-FRBA - Unidad de desarrollo e investigación de Ingeniería, Universidad Tecnológica Nacional - Facultad Regional Buenos Aires, Buenos Aires, Argentina. 


\section{Introduction}

Snow albedo is a parameter of great importance to determine the amount of solar radiation adsorbed in the cryosphere and is defined as a relationship between incoming and reflected solar radiation by a surface. Fresh snow can reflect almost completely incoming solar radiation (0.95) but can decrease to 0.45 due to metamorphism [1-4]. Snow albedo variations are influenced, among others by the surface temperature, snowfall, snow age and snow impurities [2,5-7]. Snow impurities (LAP) reduce the snow albedo and absorb more solar radiation (also called, snow darkening effect-SDE), which further accelerates the snow aging process and the melting rate of the layer of snow [8-13]. LAP and its SDE were identified as the main forcing agents that affect climate change $[14,15]$.

Estimating the snow darkening effect (SDE) through the presence of snow impurities requires a great effort of in situ measurements covering large snowy areas in many cases hardly accessible. Therefore, the level of uncertainty in the quantification of this effect continues to be very high according to the fifth assessment report (AR5) published by the Intergovernmental Panel on Climate Change (IPCC) [16]. Several studies performed in North America $[5,17,18]$ and Asia $[19,20]$ have used satellite data to study SDE in mountains with snow cover. These studies have contributed to reduce the bias related to the distribution and influence of snow impurities in form of light-absorbing particles (LAP) on the energy budget of the coupled earth atmosphere system over important areas such as the Sierra Nevada in North America and the Himalayan Mountains. Therefore, retrieved satellite remote sensing data are a good alternative to analyze data with acceptable spatial and temporal distribution covering large regions. In the Central Andes Range (Fig. 1), satellite products [mainly Moderate Resolution Imaging Spectroradiometer (MODIS)] have also been used to analyze the snow cover in the Mendoza River Basin (Argentine eastern slope of Central Andes) [21]. Recently, for the same period (2000-2016) it was established that the cover, albedo and duration of snow decreased by $13.4 \pm 4 \%, 7.4 \pm 2 \%$ and $43 \pm 20$ days, respectively [22]. A case study in the area of the sky complex in Portillo $\left(32.83^{\circ} \mathrm{S}, 70.13^{\circ} \mathrm{W}\right)$ showed a negative relationship between local vehicle emissions and the snow albedo measured in situ. However, it could not quantify the SDE from vehicular emissions [23]. The impact of changes in snow albedo during spring melting in Central Andes of Chile (CAC) generates great concern because the quantity melting and its timing are critical for the determination of water resources available to more than 7 million inhabitants [24].

Besides the above-mentioned studies, we are not aware of any other regional study in CAC on the effect of deposition of absorbent aerosols on snow surfaces and their impact on the increase in snow ablation melting in each of the basins where they feed rivers. To improve this understanding, the main objective of this study was to investigate the aerosols effect on the snow albedo reduction in several basins of the $C A C$ during the spring season, based on satellite remote sensing data for the years 2000-2016. The role aerosols that play in the negative snow albedo trend have been treated in [22], and its relationship with the distribution and local deposition of aerosols in snow has been identified in previous studies for this region [23, 25-27].

\section{Data and methodology}

To analyze the albedo reduction in the CAC $\left(30.2^{\circ} \mathrm{S}\right.$ and $34.3^{\circ} \mathrm{S}$ ), we selected the area of four basins with an elevation greater than $2000 \mathrm{~m}$ to observe the behavior on the Chilean side of the mountain range (western), as shown in Fig. 1. The Global Digital Elevation Model (GTOPO30) developed by the US Geological Survey (USGS) National Center for Earth Resources Observation and Science (EROS) Data Center with a $1 \mathrm{~km}$ resolution was used as surface topography (https://www.usgs.gov/centers/eros/ science/usgs-eros-archive-digital-elevation-global-30-arcsecond-elevation-gtopo30).

Daily satellite data of snow cover (SC), snow albedo (SA), land surface temperature (LST), aerosol optical depth (AOD) and precipitation $(P)$ were retrieved and analyzed (Table 1). SC and SA were retrieved from MODIS images [28-30]. MODIS products consider slopes and snow cover on mountainous surfaces $[19,28]$. The LST product was used $[9,31]$ and has been shown to be suitable for mountainous areas (Alto del Rio Grande River Basin) with a high agreement of $86 \%$ [32]. The AOD aerosol product was retrieved from MOD04 [33] using the wavelength of $0.55 \mu \mathrm{m}$, the wavelength where the snow albedo presented the highest variability due to light-absorbing particles $[2,23,34]$. Precipitation was retrieved from the Tropical Rainfall Measuring Mission (TRMM) [35-37]. TRMM provided not only spatial information on rainfall, but also vertical profiles of precipitation, and therefore, it has been proven suitable for the present study $[35,38]$.

Clouds presence produced very frequently missing satellite data (daily). Therefore, we used a series of 17 years of daily data of the austral spring (September to November from 2000 to 2016) to minimize gaps and produce a more reliable statistic. Since TRMM detects only liquid precipitation, a parameter was generated to estimate the days where precipitation was snow, by detecting temperatures below the freezing level at $-4^{\circ} \mathrm{C}$, taking the uncertainties of MOD11 measurements into account [39]. The number of 
Fig. 1 Basins and elevation map of the Central Andes mountains. Blue line represents the area over $2000 \mathrm{~m}$ a.s.l. in the basins of the western Andes of Chile

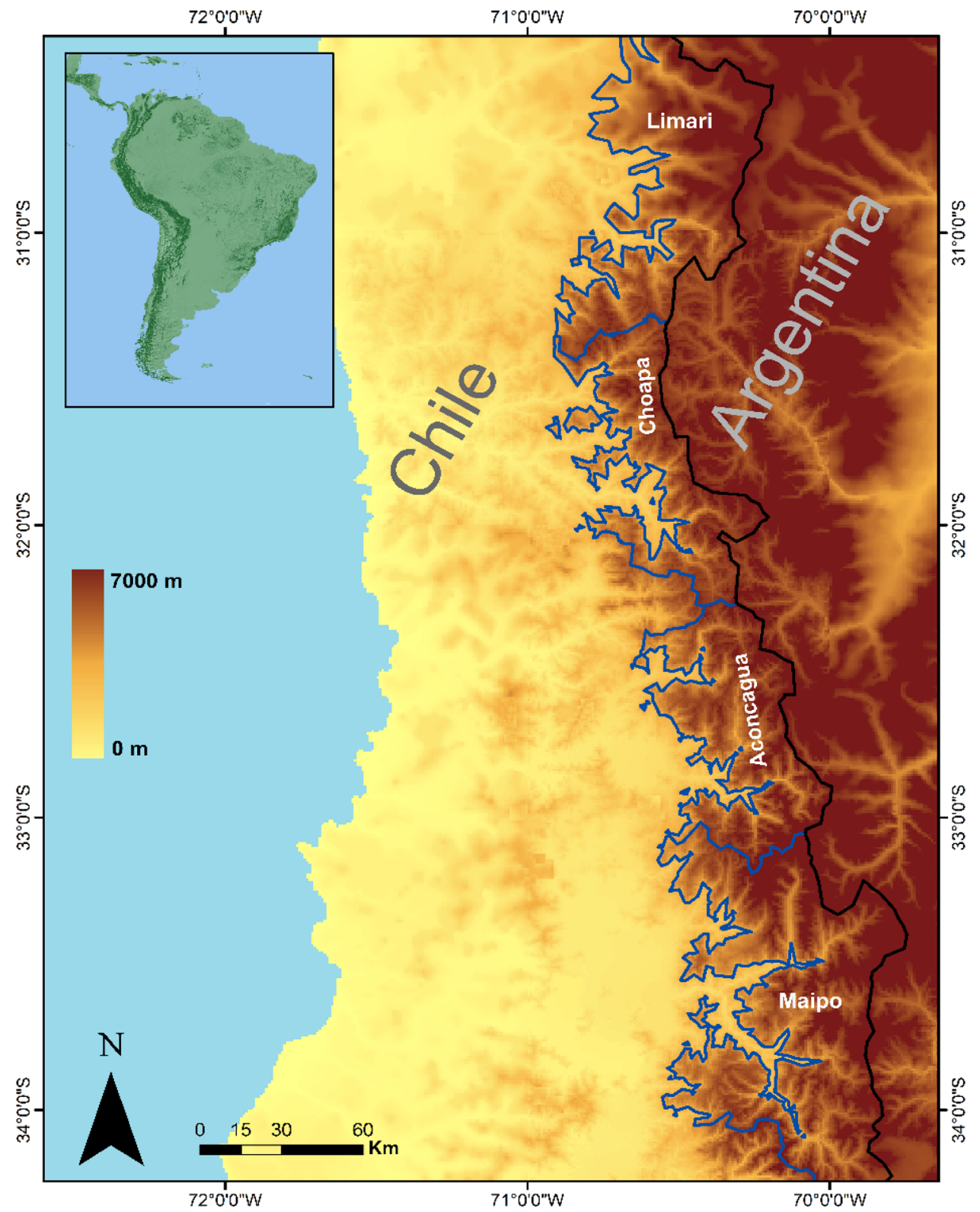

Table 1 Data retrieved from used satellite products

\begin{tabular}{llll}
\hline Parameter & $\begin{array}{l}\text { Used satellite } \\
\text { product }\end{array}$ & $\begin{array}{l}\text { Spatial resolu- } \\
\text { tion }(\mathrm{km})\end{array}$ & Pixels used \\
\hline SC & MOD10 & 0.5 & $100 \%$ \\
SA & MOD10 & 0.5 & All pixels with \\
LST & MOD11 & 1 & $\begin{array}{l}100 \% \text { snow } \\
\text { cover }\end{array}$ \\
AOD & MOD04 & 10 & \\
P & $3 B 42$ & 25 & \\
\hline
\end{tabular}

days between snowfalls was also estimated by a parameter called days after snow (DAS).

The daily data sets were analyzed by means of box and whisker plot allowing to observe the variability and skewness of the data and if so, in what direction. To estimate the effect of aerosol deposition on the SA reduction in each basin, the correlation of SA to LST, AOD, snow precipitation (SP) and DAS was investigated by means of a multiple regression analysis for all available data sets per basin. Finally, in a case study we ran the numerical prediction Weather Research and Forecasting model coupled with Chemistry (WRF-Chem) [44] for a few selected days and compared them with the average of snow albedo (SA) and AOD data retrieved over two basins. To estimate the regional source of black carbon $(B C)$, we studied the west winds that drag air masses toward the high areas of the basins studied using WRFChem and backward trajectories using NOAA HYSPLIT $[40,41]$. 


\section{Analysis and discussion}

\subsection{Observational data}

Figure 2 shows the daily distribution of SA, LST, AOD, DAS and SP for each basin of the western slope of the Central Andes in Chile for the spring months of September to November for the years 2000-2016. The Limari and Maipo
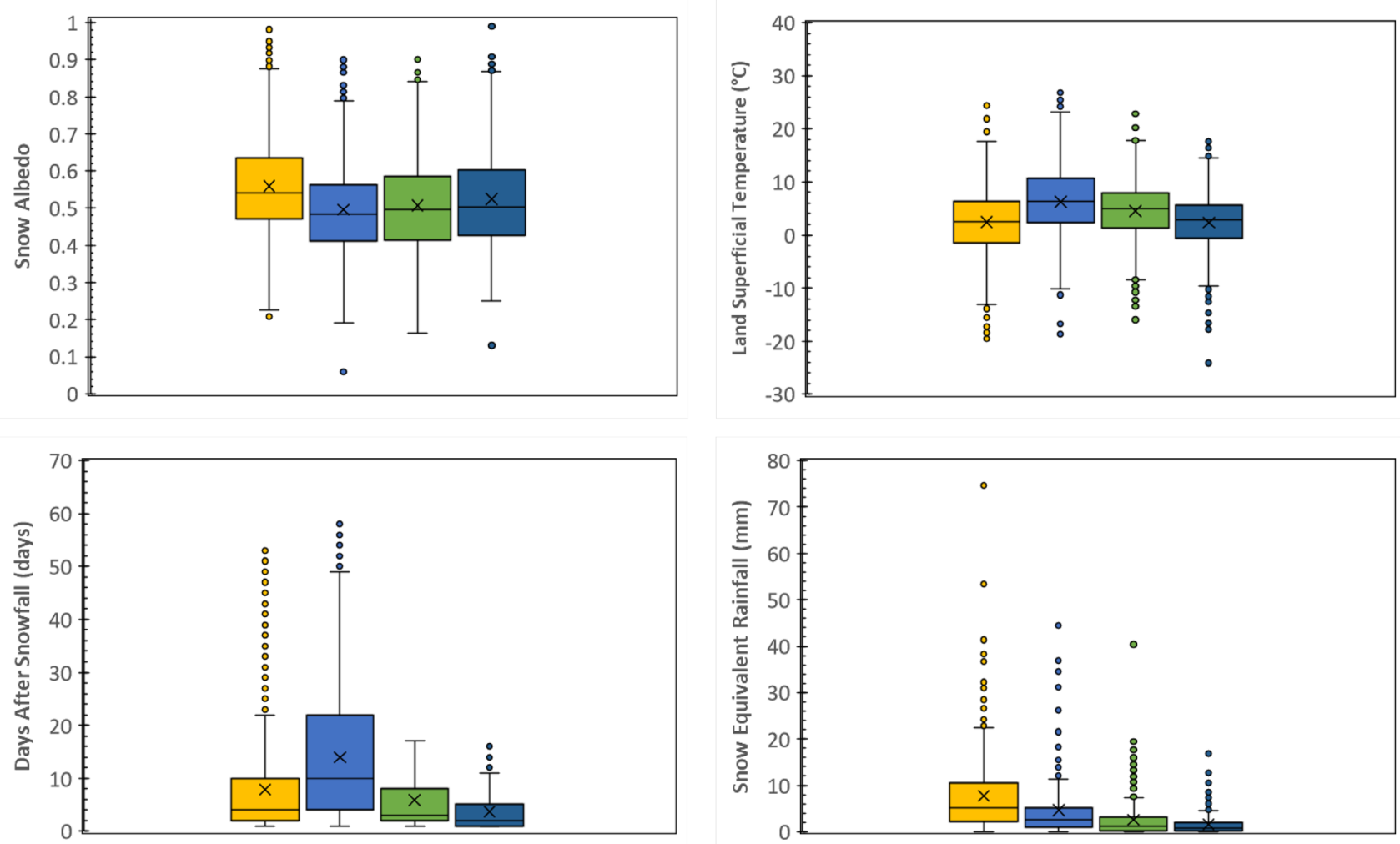

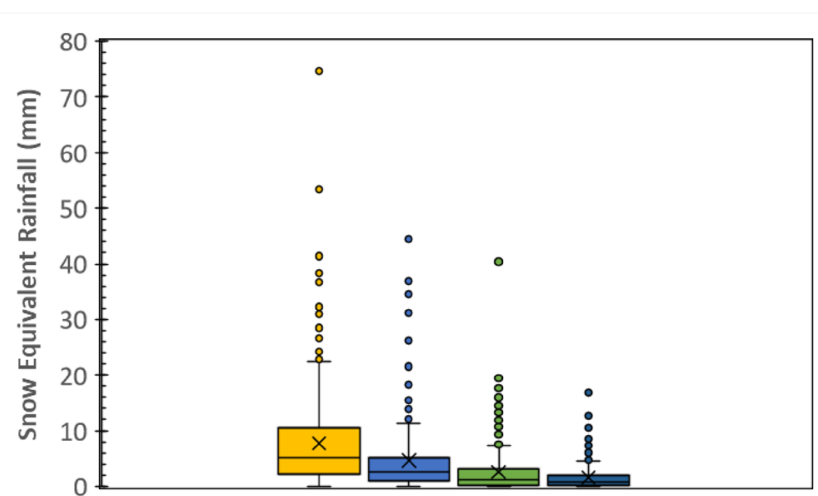

basins presented extreme values of SA higher than 0.9, while Choapá presented the lowest extreme value (less than 0.1). The AOD showed low average values overall with the highest average value in the Limari basin and the highest number of extreme values in Maipo (up to 0.42). This high value of $A O D$ was related to the presence in this basin of the largest urban area of Chile (Santiago). Contaminants in snow from this city have been identified in other studies [25]. Land surface temperatures (LST) showed values

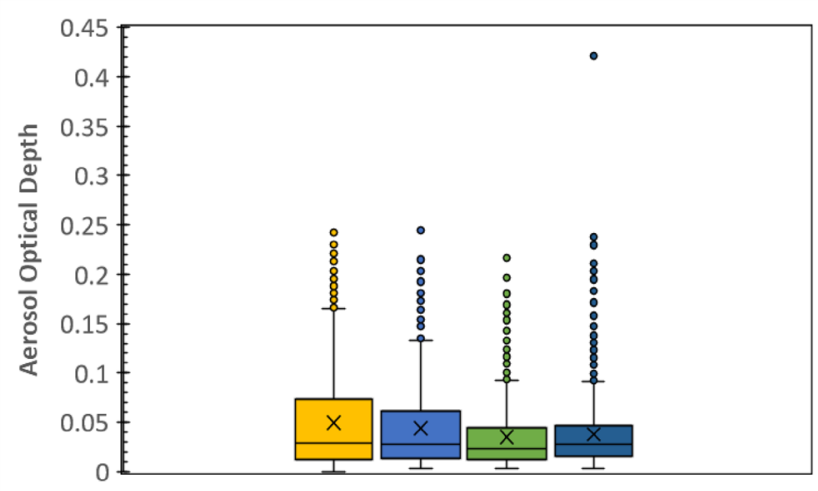

Limari $\square$ Choapa $\square$ Aconcagua $\square$ Maipo

Fig. 2 Daily averages of snow albedo (upper left panel), land surface temperature (upper right panel), days after each snowfall event (center left panel), snow equivalent rainfall (center right panel) and aerosol optical depth (lower center panel) for pixels

\section{SN Applied Sciences}

with $100 \%$ snow cover, and to each basin area in spring season from 2000 to 2016. Bars indicate quartile 1 and quartile 2, and points are extreme values outside of interquartile range 
around $0{ }^{\circ} \mathrm{C}$ in the Limari and Maipo basins; in Choapá and Aconcagua, they were slightly around $4{ }^{\circ} \mathrm{C}$. Snow precipitations (SP) had a decreasing trend from Limari (north) to Maipo (south) indicating how the last spring snowfalls contributed to recover the snow albedo (SA), as observed in Limari where the highest amount of snowfalls and average SA is higher. The highest average DAS was observed in Choapá (11.7 days), also the basin with the lowest average SA and highest LST.

The snow albedo (SA) in each basin presented an asymmetry toward high and positive values. The Limari basin had the highest average albedo, and this was related to the lowest surface temperature (LST) values observed on this same basin due to the higher average of snow equivalent rainfall. The lowest average values of SA were observed on the Choapá basin, which is related to the highest average LST values generating the greatest number of days without snowfall. The average values of AOD decreased from north to south of the analyzed basins, an opposite trend to the SA showing an increase in the averages observed from Choapá basin to the south. The analysis of the daily data Fig. 2 showed that the observed data have a good approximation to the expected physical behavior for SA on all basins [34, 42, 44]. In addition, AOD data from MODIS are consistent with the average values of AOD anomalies observed from the SeaWiFS sensor, where high values decreased toward the southern basins during the austral spring months (shown in Fig. 3). It is thus reasonable to use a linear multiple regression to try to explain the relationship between a dependent variable (SA as response variable) and a set of independent variables (explanatory variables as LST, AOD, SP and DAS, respectively).

To analyze the relationship between SA and LST, AOD, DAS and SP, we calculated the correlation coefficients $(r)$ using their monthly averages from September to November during 2000-2016, as shown in Table 2. These correlations show that the LST has the greatest impact on the SA. Furthermore, the sign coincides with the expected effect on the snow albedo: SA decreases with LST, AOD, DAS and increases with the SP $[2,34,42,43]$.

The correlation coefficients analysis ( $r$ ) shows that LST, AOD, DAS and SP are not linearly independent. However, sometimes the relationship is not linear using only one parameter. Therefore, we utilized a multiple linear regression technique to evaluate the AOD impact on the SA decrease [5]. We used a multiple linear regression technique, standardizing the data with its standard deviations, for the austral spring months (2000-2016) for each parameter obtaining the following relations: (shown in Eqs. 1-4).

$$
\begin{aligned}
\mathrm{SA}_{\mathrm{L}}= & -1.15 \times 10^{-15}-0.6 \mathrm{LST}_{\mathrm{L}}-0.36 \mathrm{AOD}_{\mathrm{L}} \\
& +0.072 \mathrm{PS}_{\mathrm{L}}-0.148 \mathrm{DAS}_{\mathrm{L}}
\end{aligned}
$$

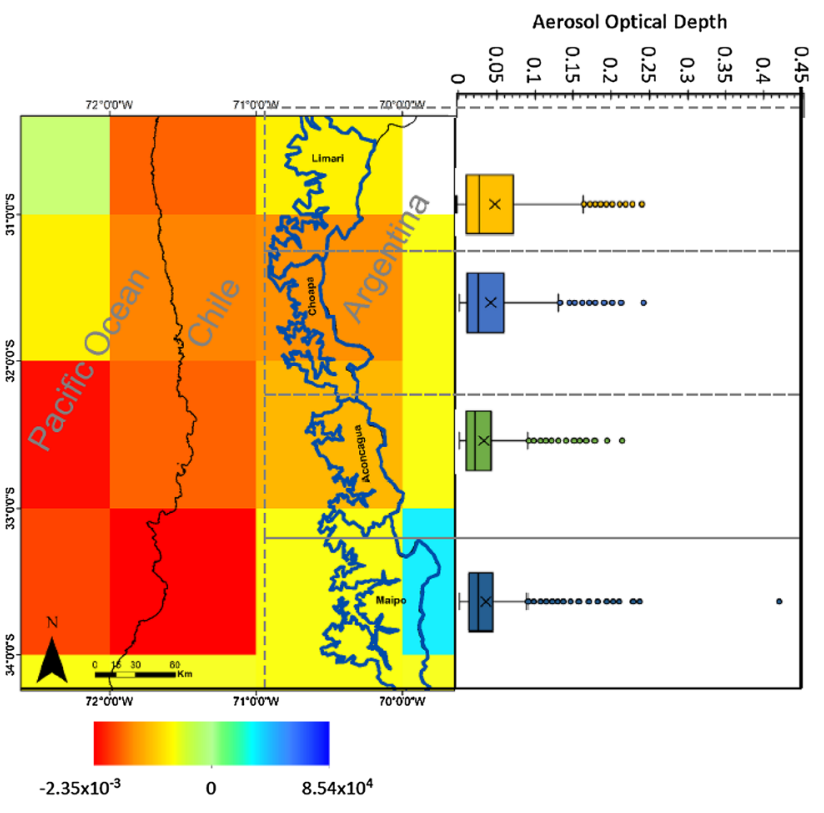

Fig. 3 Average anomaly of aerosol optical depth $550 \mathrm{~nm}$ monthly 1 deg (SeaWiFS SWDB_L3MCA10 v004) for spring months from Sep 1997 to Nov 2010 (left panel). Seasons with missing months were discarded. Analyses and visualizations used in this figure were produced with the Giovanni online data system, developed and maintained by the NASA GES DISC. Right panel: Daily averages of aerosol optical depth for pixels with $100 \%$ snow cover, and to each basin area in spring season from 2000 to 2016. Graydotted line encloses each basin and relates the average values of monthly (anomaly) and daily aerosol optical depth for the same area, respectively

$$
\begin{aligned}
\mathrm{SA}_{C}= & -2.43 \times 10^{-15}-0.833 \mathrm{LST}_{C}-0.101 \mathrm{AOD}_{\mathrm{C}} \\
& +0.038 \mathrm{SP}_{\mathrm{C}}-0.009 \mathrm{DAS}_{C} \\
\mathrm{SA}_{\mathrm{A}}= & -2.51 \times 10^{-15}-0.754 \mathrm{LST}_{\mathrm{A}}-0.027 \mathrm{AOD}_{\mathrm{A}} \\
& +0.189 \mathrm{SP}_{\mathrm{A}}-0.109 \mathrm{DAS}_{\mathrm{A}} \\
\mathrm{SA}_{\mathrm{M}}= & -0.0368-0.56 \mathrm{LST}_{\mathrm{M}}-0.111 \mathrm{AOD}_{\mathrm{M}} \\
& +0.563 \mathrm{SP}_{\mathrm{M}}-0.096 \mathrm{DAS}_{\mathrm{M}}
\end{aligned}
$$

Table 2 Correlation coefficients ( $r$ ) of SA with LST, ADO, DAS and SP for each basin of the study area

\begin{tabular}{lllll}
\hline Basin & LST & AOD & SP & DAS \\
\hline Limari & -0.86 & -0.63 & 0.12 & -0.60 \\
Choapa & -0.87 & -0.37 & 0.15 & -0.49 \\
Aconcagua & -0.84 & -0.29 & 0.60 & -0.33 \\
Maipo & -0.86 & -0.23 & 0.70 & -0.17 \\
\hline
\end{tabular}


We then calculated 51 datapoints from monthly averages in each basin (all spring months 2000-2016) for analyzing the relation of the parameters (independent variables) with the SA. Snow albedo comparisons between satellite retrievals and the $S A$ calculated with the multiple regression equations (Fig. 4) and show a confidence level of $95 \%$ and a low mean absolute percentage error (MAPE), indicating that the equations explain more than $74 \%$ (based on the minimum calculated $R^{2}$ ) of the $S A$ variation. All the equations show that a larger LST, AOD and DAS lead to a lower surface albedo (SA), which coincides with the physical behavior of melting snow. When surface temperature (LST) increases, it also increases the snow grains. Impurities on the snow increase the absorbed radiation, and since older snow is darker, this leads to a lower SA [1, 42]. The low MAPE indicates that the performance of this regression model is reasonably good.

To estimate the LST, AOD, PS and DAS contributions to the behavior of $S A$, we used the difference of the normalized mean values of LST, AOD, DAS and SP for the spring months (September to November, years 2001-2016). Table 3 shows the contribution percentage of each parameter to SA. The multiple regression model predicts that the AOD is the third parameter that most contributes to SA decrease after LST and DAS, respectively. AOD has a higher contribution to the SA (13.59\%) in the basin located further north (Limari). On the other hand, snowfalls (SP)
Table 3 Contribution percentage to SA of each parameter for the data sets and basins analyzed using the multiple regression model

\begin{tabular}{lcrrr}
\hline Basin & $\%$ LST & \% AOD & \% SP & \% DAS \\
\hline Limari & 72.40 & 13.59 & 3.76 & 10.26 \\
Choapa & 98.27 & 0.01 & 0.02 & 1.71 \\
Aconcagua & 74.80 & 0.77 & 14.76 & 9.67 \\
Maipo & 62.60 & 3.80 & 30.27 & 3.33 \\
\hline
\end{tabular}

contributed mainly to the SA recovery in the two basins located further south of the study area.

\subsection{Case study using WRF-Chem model}

To further investigate the influence of absorbent aerosols distribution on the decrease in albedo (SA) as identified by the multiple linear regression model, we selected the two basins that have the highest percentage of influence of AOD in the SA decrease (Limari and Maipo) (Table 3). Temporal distribution observed on the Limari and Maipo basins from September 26 to 30, 2016, shows that with a 1-day AOD delay over the SA (Fig. 5), the expected behavior of the AOD over the SA coincides with what is expected intuitively and predicted by the multiple regression model. We consider that the 1-day delay of $A O D$ with respect to the $S A$ is a consequence
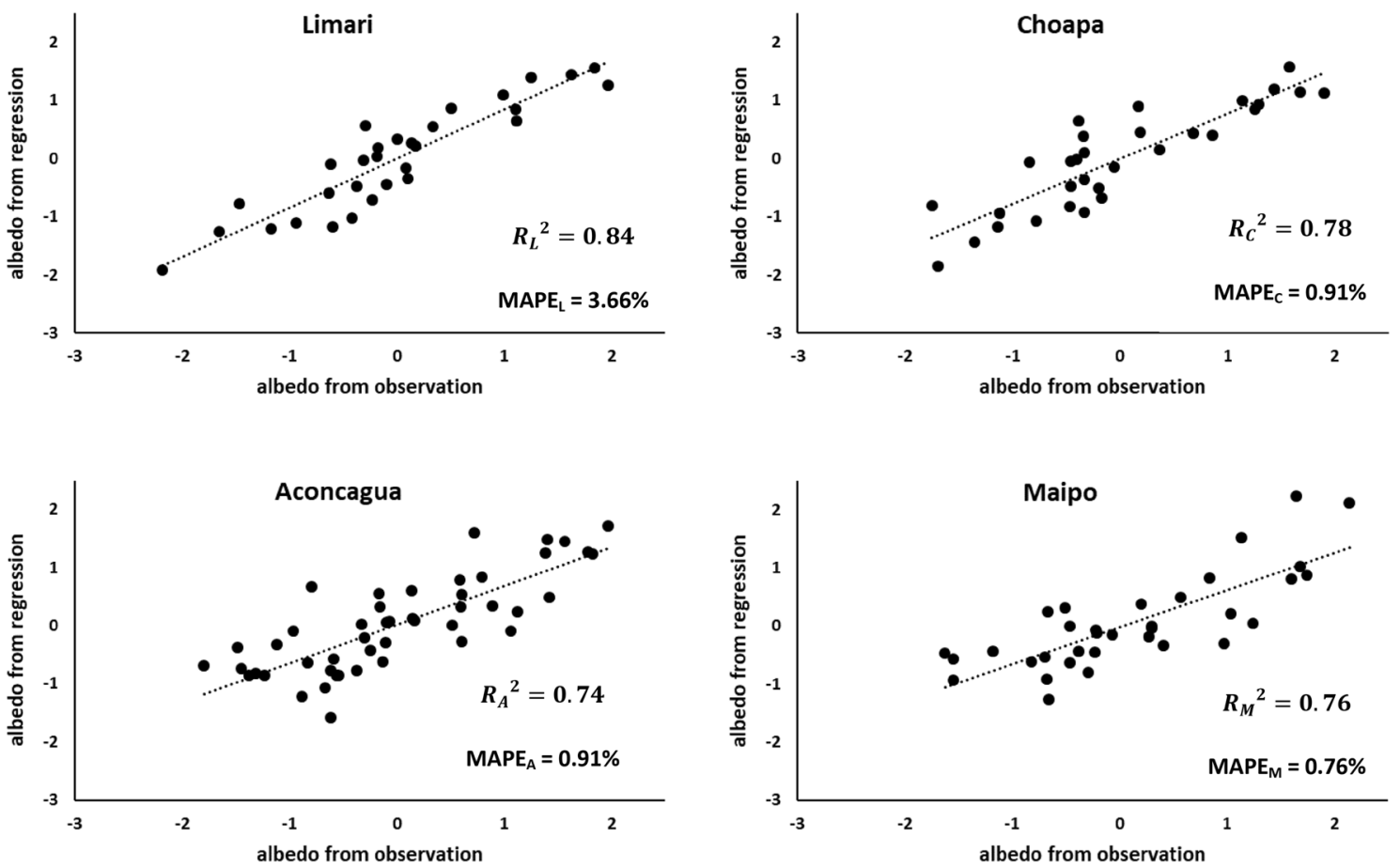

Fig. 4 Comparison of the snow albedo predicted by the multiple regression equation determined from satellite retrievals over each basin studied (normalized values). Dashed lines display the linear trend estimation 

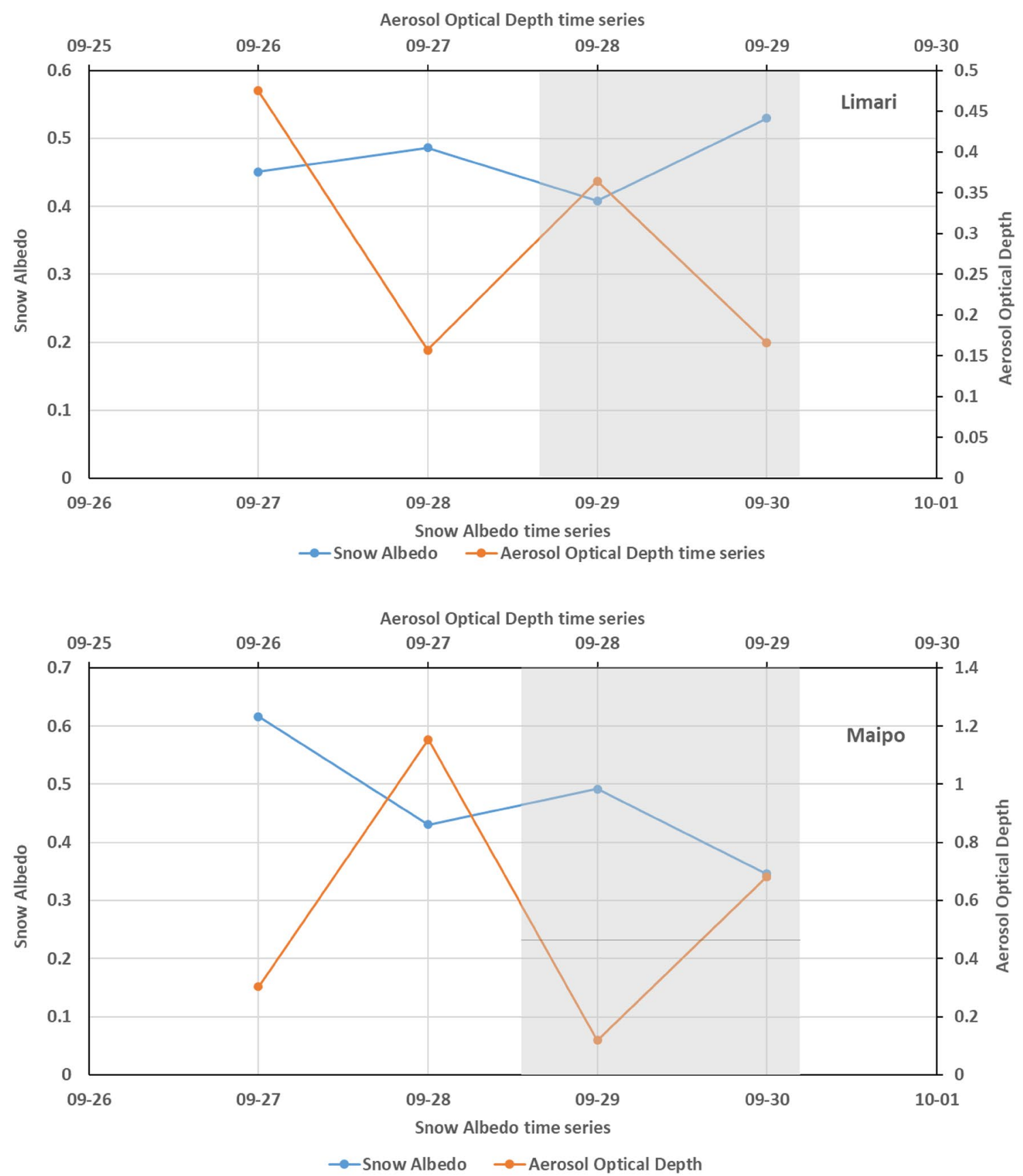

Fig. 5 Daily average of snow albedo and optical depth of aerosols for pixels with 100\% snow cover to each basin during 4 consecutive days in September 2016 on Limari and Maipo basin. Gray-shaded area indicates days analyzed in the WRF-Chem model

of transport time and deposition rate [45]. Moreover, the measuring satellite passes by the study area early on the day, and, therefore, the effect of the aerosol deposited would occur in the course of the day when the snow cover receives radiation from the sun. For the particular analyzed days, the sunrise and sunset were at 6:24 and 18:44 local time, respectively (i.e., $12.3 \mathrm{~h}$ of solar irradiation). However, the satellite that captured the AOD measurement passed at 10:45 and 9:45 local time on September 28 and 29, respectively; therefore, the effect of the measured AOD on the SA (during the rest of the solar day: 8 and 9 h, respectively) will be better observed on the next day. 


\subsubsection{WRF-Chem modeling}

To analyze the contribution of aerosol to the studied basins, we run a numerical meteorological prediction model, the Weather Research and Forecast with Chemistry (WRF-Chem) [46]. This model was used with a parametrization shown in Suppl. Mat. Table S1, which was already tested in this region [47-50]. WRF-Chem model was run using three nested domains (shown in Suppl. Mat. Fig. S1) and was verified using vertical profiles of several meteorological variables for September 28 and 29, 2016 (shown in Suppl. Mat. Figs. S2 and S3, respectively). Aerosol deposition as light-absorbing particles $(B C)$ is very efficient to decrease the snow albedo [34,51-54], and we used $B C$ to simulate and estimate the distributions over the basins of the study area (Fig. 1). We expected the aerosol to come mainly from dominating westerly wind in the Central Andes [55-57] from the urban and industrial areas of Chile and moving toward the higher altitudes of the basins covered with snow [25]. For the two selected basins (with higher influence of the aerosols in the decrease in snow albedo, according to the regression model in Table 3), we recovered as an output from the WRF-Chem model, the daily averages of SA and AOD for pixels with $100 \%$ snow cover (shown in Fig. 5).

The WRF-Chem model outputs indicate predominant winds from west to east for two days, with a spatial resolution of $4 \mathrm{~km}$ and 48 vertical levels. On 28 September, the Limari basin showed maximum BC values of $0.24 \mu \mathrm{g} /$ $\mathrm{kg}_{\text {dry air }}$ dropping to at least $0.04 \mu \mathrm{g} / \mathrm{kg}_{\text {dry air }}$ (Fig. 6), while on 29 September, the AOD decreased from 0.36 to 0.16 . In Maipo basin, the BC value on September 28 was $0.20 \mu \mathrm{g} /$ $\mathrm{kg}_{\text {dry air }}$ and increased the next day to $0.42 \mu \mathrm{g} / \mathrm{kg}_{\text {dry air }}$ while the AOD observed for these days was 0.12 and 0.68 , respectively (Fig. 7). Both the decreasing (Limari) and increasing (Maipo) trends of $B C$ concentrations coincided with the behavior observed in Fig. 5 for the average AOD in the pixels of $100 \%$ in SC on 28 and 29 September. Predominant wind directions during these days (in Valparaiso) showed west components (Fig. 8). In addition, the BC distribution according to the WRF-Chem model and the average daily AOD are associated with a decrease in SA of 0.15 in the Maipo basin (Fig. 5) between September 29 and 30, 2016.

The Limari and Maipo basins have an average slope of 35.87 and $5.23 \%$, respectively, in addition to a height of almost $5000 \mathrm{~m}$ a.s.l. Other studies in mountainous areas have shown that aerosol removal by deposition is efficient in high mountains [5, 58-60]. Therefore, our BC distribution and transport by westerly winds confirm the

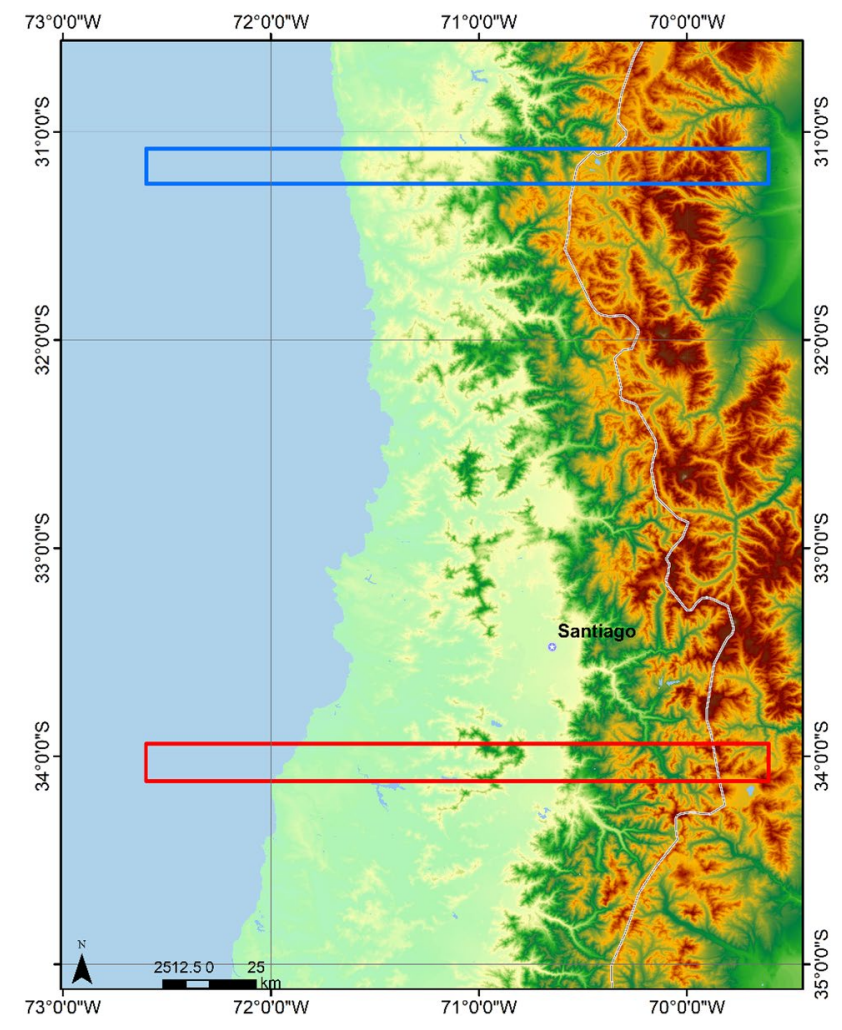

Fig. 6 Case study area using WRF-Chem model: blue and red lines represent latitudinal transept on Limari and Maipo basin for the days September 28 and 29, 2016

prediction of our multiple regression model on the influence of aerosols on the SA decrease for the period of time analyzed.

Also, both estimated maximum values of $B C$ were better explained by higher AOD and the air mass transport patterns by NOAA HYSPLIT model outputs (Fig. 9) $[40,41]$. The peak AOD on 28 and 29 September originated from the anthropogenic emission source with a higher AOD in the Santiago Metropolitan and IV Region areas, where many urban, industrial and mining activities in Chile are present [61-66].

The snowpack in the studied area is a very important source of water supply in central Chile because snow stores fresh water during the cold and wet season and then gradually releases water during warm season, representing an important contribution to the river flows of this region $[67,68]$. In addition, several studies suggest that a snowpack reduction in this mountain area has 


\section{Limari}

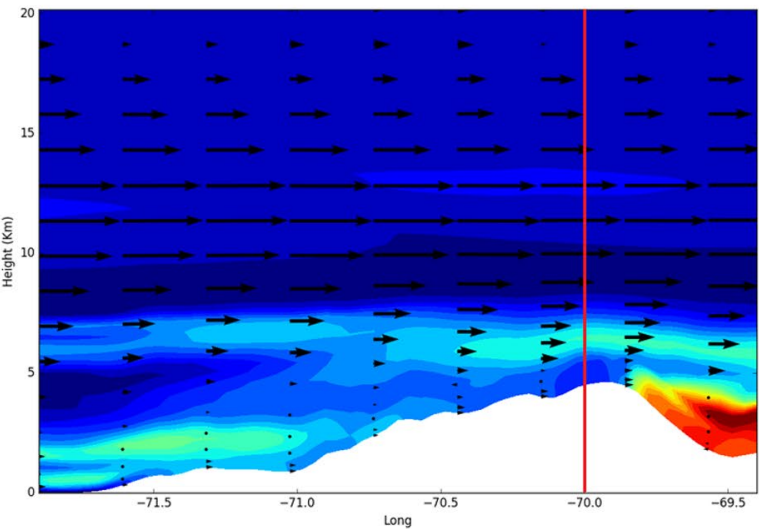

Sep 28, 2016

Maipo

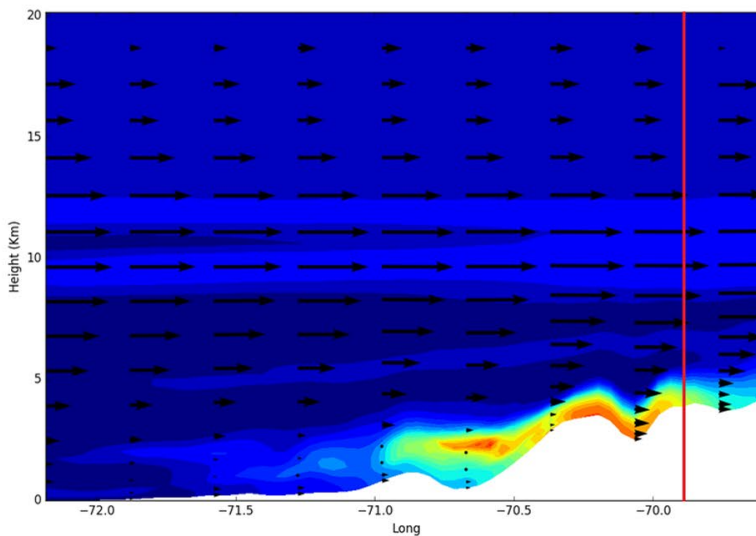

Sep 29, 2016
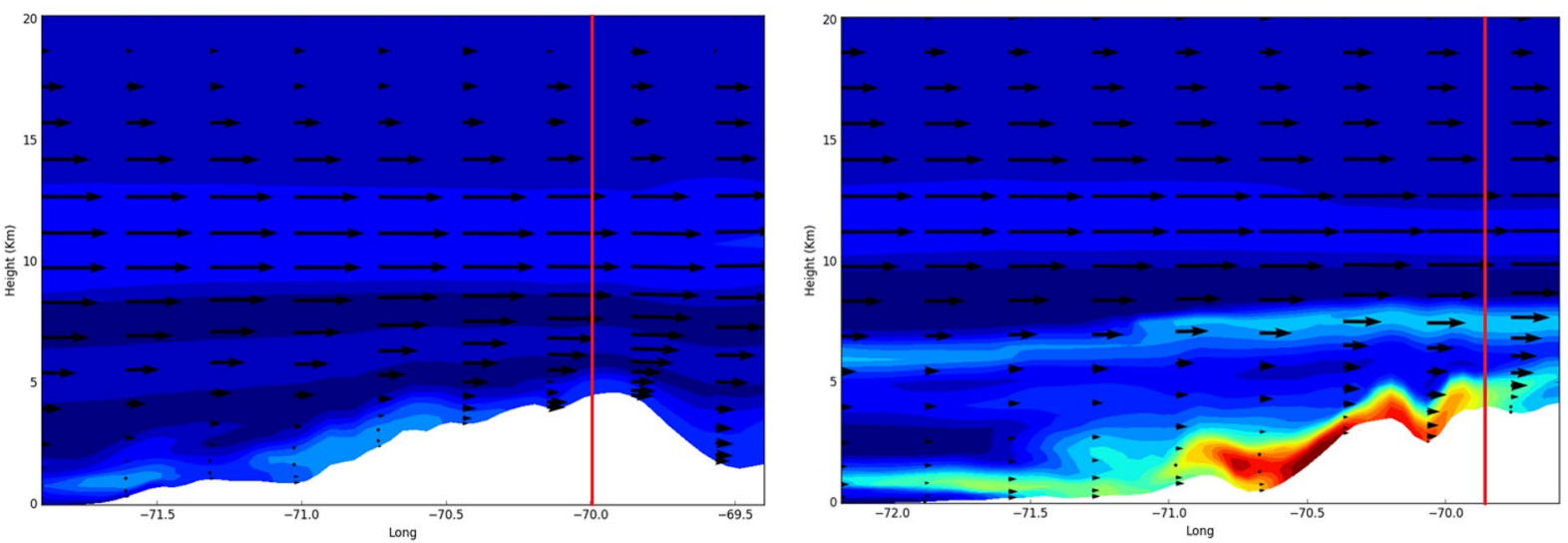

show wind direction, white area indicates latitudinal transect through the Andes mountain range, and red lines show a transect at the highest point of the east and border with Argentina impacts on the hydrological cycle and the water supply for the region $[57,68,69]$. The variations and high absorbent aerosols deposited in the snow analyzed in this study suggest that the sources of anthropogenic aerosols may be playing a role in the availability of water through a positive effect with solar radiation.

\section{Conclusions}

Our research on the effect of aerosols on the snow albedo (SA) shows that the SA average does not exceed 0.55 for the whole study area. The Limari and Maipo basins located more to the north and south, respectively, were the only ones with extreme values higher than 0.9 . The average SA was the lowest in Choapá due to the increase in LST and DAS. Snow precipitation (SP) showed to be the most important parameter contributing to the increase in SA in Limari, despite a high DAS, the high SP (in comparison with the other basins) produced the lowest LST and the highest SA average. In Limari, the $A O D$ average was the highest. The multiple linear regression model including the LST, AOD, SP and DAS explains $84,87,74$ and $76 \%$ of the variation in snow albedo in the Limari, Choapá, Aconcagua and Maipo basins, respectively. In addition, we evaluated the regression model with the maximum differences observed in the study period. The prediction of the regression equation 


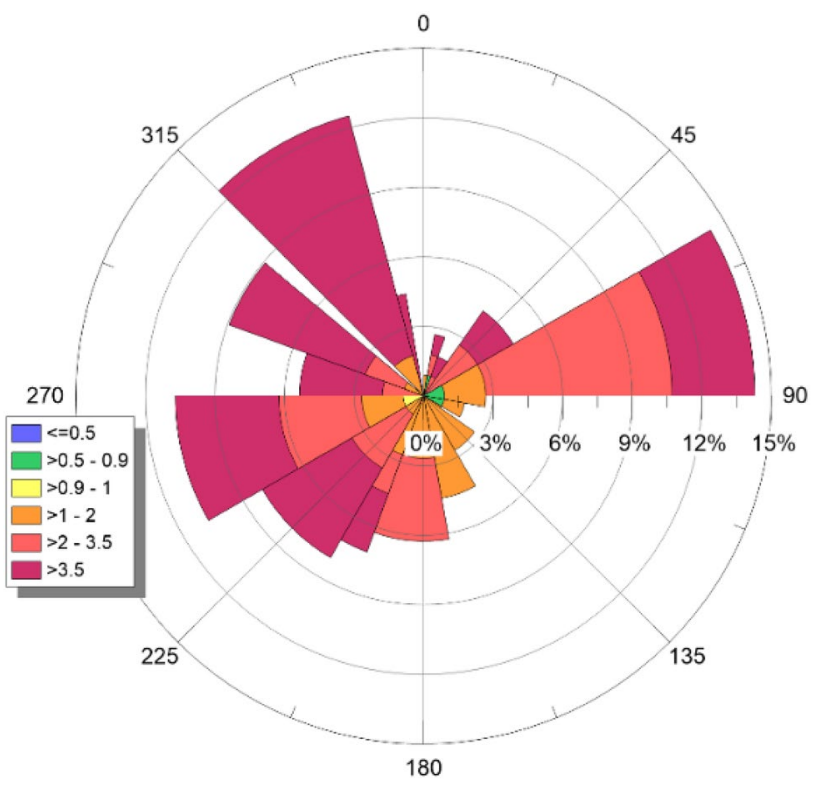

Fig. 8 Wind rose for wind speed $(\mathrm{m} / \mathrm{s})$ and direction for September 26 to 30, 2016. Observed date measured at $40 \mathrm{~m}$ in height at the main Weather Station located in Valparaiso, Chile (https://sinca .mma.gob.cl/index.php/estacion/index/id/140) shows that approximately $13.59,0.01,0.77$ and $3.8 \%$ of the snow albedo reduction in the spring months in Limari, Choapá, Aconcagua and Maipo, respectively, are due to an increase in AOD. Our results suggest that decreases in SA due to AOD are correlated with the air masses originating from the largest industrial and urban areas in Chile. WRF-Chem modeling of a case study in the Limari and Maipo basins showed that, especially in the Maipo basin, the $\mathrm{BC}$-modeled distribution and the average daily $A O D$ are associated with a decrease in the SA. Also, there is a predominance of westerly winds bringing in air masses, containing high BC content, generated by anthropogenic activities from the region of Santiago de Chile and the $V$ region as shown on backward trajectories simulated by NOAA HYSPLIT. Future research should consider the potential effects of LAP over the local radiative forcing, as well as model improvements for the analysis of WRF-Chem simulations to improve knowledge on the impact of such impurities in snow on surface energy and water budgets in this region.
NOAA HYSPLIT MODEL

Backward trajectories ending at 2000 UTC 29 Aug 16 GFSG Meteorological Data

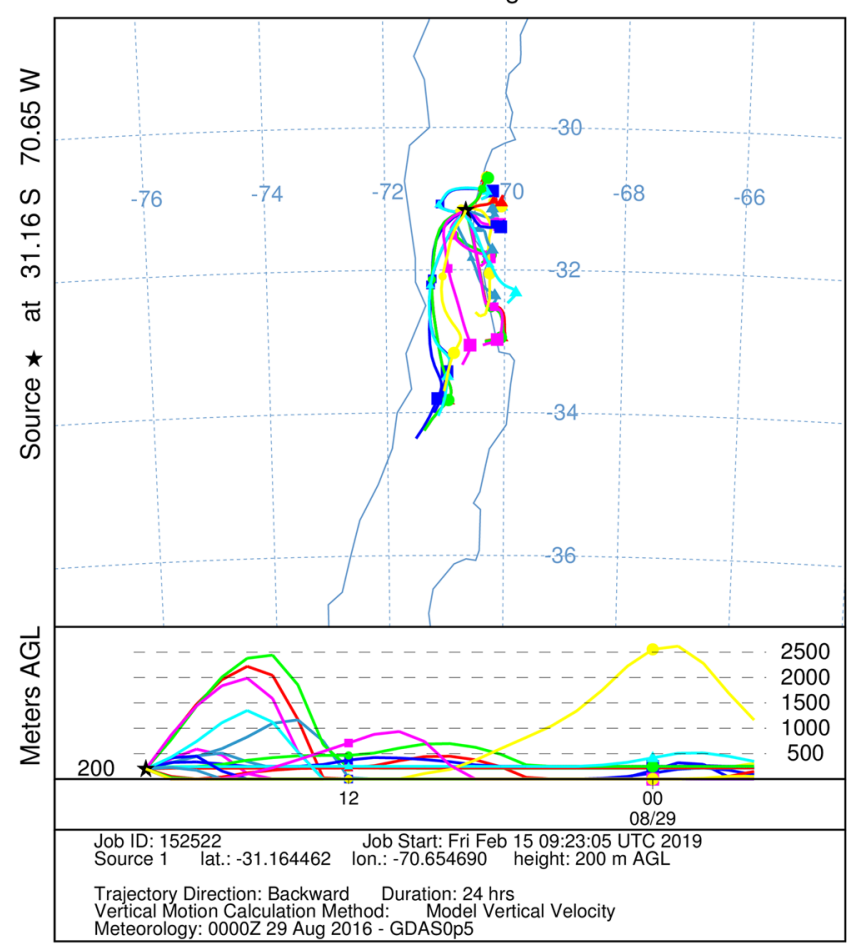

NOAA HYSPLIT MODEL

Backward trajectories ending at 2000 UTC 29 Aug 16 GFSG Meteorological Data

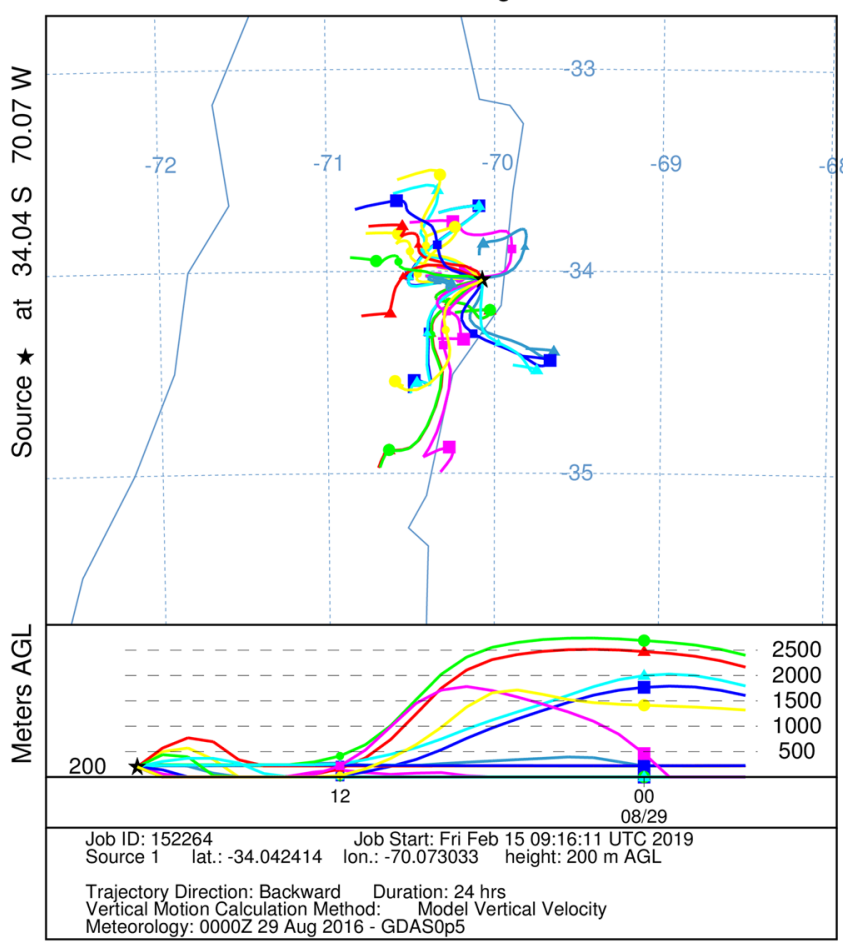

Fig. 9 Backward trajectories (ensemble) simulated by NOAA HYSPLIT ending at 20:00UTC on September 29, 2016, in Limari and Maipo 
Acknowledgements This work was supported by Universidad Tecnológica Nacional (UTN IFI Projects PID 1799 and 1487, CONICET (CONICET PIP 11220110100673 and PICT 2016 1115), and the authors are thankful to FCE UNCUYO for allowing to run the WRFChem model on its cluster. We also acknowledge the MODIS, SRTM DEM and NOAA HYSPLIT mission scientists and associated personnel for the production of the data used in this research effort. All data requests should be addressed to the first author.

\section{Compliance with ethical standards}

Conflict of interest The authors declare that they have no conflict of interest.

\section{References}

1. Cuffey KM, Paterson WSB (2010) The physics of glaciers. Academic Press, Cambridge

2. Qian Y, Yasunari TJ, Doherty SJ, Flanner MG, Lau WKM, Ming J et al (2015) Light-absorbing particles in snow and ice: measurement and modeling of climatic and hydrological impact. Adv Atmos Sci. https://doi.org/10.1007/s00376-014-0010-0

3. Qian Y, Wang H, Zhang R, Flanner MG, Rasch PJ (2014) A sensitivity study on modeling black carbon in snow and its radiative forcing over the Arctic and Northern China. Environmental Research Letters. https://doi.org/10.1088/1748-9326/9/6/06400 1

4. Flanner MG, Zender CS, Hess PG, Mahowald NM, Painter TH, Ramanathan V, Rasch PJ (2009) Springtime warming and reduced snow cover from carbonaceous particles. Atmos $\mathrm{Chem}$ Phys 9(7):2481-2497. https://doi.org/10.5194/acp-9-2481-2009

5. Lee W-L, Liou KN (2012) Effect of absorbing aerosols on snow albedo reduction in the Sierra Nevada. Atmos Environ 55:425430. https://doi.org/10.1016/j.atmosenv.2012.03.024

6. Warren SG, Wiscombe WJ (1980) A model for the spectral albedo of snow. II: snow containing atmospheric aerosols. J Atmos Sci 37(12):2734-2745. https://doi.org/10.1175/15200469(1980)037\%3c2734:amftsa\%3e2.0.co;2

7. Levy RC, Remer LA, Mattoo S, Vermote EF, Kaufman YJ (2007) Second-generation operational algorithm: retrieval of aerosol properties over land from inversion of Moderate Resolution Imaging Spectroradiometer spectral reflectance. Journal of Geophysical Research: Atmospheres. https://doi.org/10.1029/2006j d007811

8. Hansen JE, Sato M (2001) Trends of measured climate forcing agents. Proc Natl Acad Sci USA 98(26):14778-14783. https://doi. org/10.1073/pnas.261553698

9. Pepin N, Bradley RS, Diaz HF, Baraer M, Caceres EB, Forsythe N et al (2015) Elevation-dependent warming in mountain regions of the world. Nature Climate Change. https://doi.org/10.1038/ nclimate2563

10. Clarke AD, Noone KJ (1985) Soot in the Arctic snowpack: a cause for perturbations in radiative transfer. Atmos Environ 19(12):2045-2053. https://doi.org/10.1016/0004-6981(85)90113 $-1$

11. Warren SG, Wiscombe WJ (1985) Dirty snow after nuclear war. Nature 313(6002):467-470. https://doi.org/10.1038/313467a0

12. Menon S (2002) Climate effects of black carbon aerosols in China and India. Science 297(5590):2250-2253. https://doi. org/10.1126/science.1075159

13. Hansen J, Sato M, Ruedy R (1997) Radiative forcing and climate response. Journal of Geophysical Research: Atmospheres 102(D6):6831-6864. https://doi.org/10.1029/96jd03436
14. IPCC (2007) Climate Change 2007-the physical science basis: working group I contribution to the fourth assessment report of the IPCC. Cambridge University Press, Cambridge

15. Griggs DJ, Noguer M (2002) Climate change 2001: the scientific basis. Contribution of working group I to the third assessment report of the intergovernmental panel on climate change. Weather 57:267-269. https://doi.org/10.1256/0043165023 20517344

16. IPCC (2013) Fifth assessment report-Climate Change 2013. IPCC, Geneva. https://doi.org/10.1126/science.1061457

17. Painter TH, Rittger K, McKenzie C, Slaughter P, Davis RE, Dozier $J$ (2009) Retrieval of subpixel snow covered area, grain size, and albedo from MODIS. Remote Sens Environ 1:1. https://doi. org/10.1016/j.rse.2009.01.001

18. Naeger AR (2018) Impact of dust aerosols on precipitation associated with atmospheric rivers using WRF-Chem simulations. Results in Physics 10:217-221. https://doi.org/10.1016/j. rinp.2018.05.027

19. $\mathrm{Pu} \mathrm{Z,} \mathrm{Xu} \mathrm{L,} \mathrm{Salomonson} \mathrm{VV} \mathrm{(2007)} \mathrm{MODIS/Terra} \mathrm{observed} \mathrm{sea-}$ sonal variations of snow cover over the Tibetan Plateau. Geophys Res Lett 34(6):L06706. https://doi.org/10.1029/2007G L029262

20. Yasunari TJ, Tan Q, Lau K-M, Bonasoni P, Marinoni A, Laj P et al (2013) Estimated range of black carbon dry deposition and the related snow albedo reduction over Himalayan glaciers during dry pre-monsoon periods. Atmos Environ 78:259-267. https:// doi.org/10.1016/j.atmosenv.2012.03.031

21. Cara L, Masiokas M, Viale M, Villalba R (2016) Análisis De La Cobertura Nival De La Cuenca Superior Del Río Mendoza a Partir De Imágenes Modis. Meteorológica 41:21-36. https:// doi.org/10.1097/j.pain.0000000000000613

22. Malmros JK, Mernild SH, Wilson R, Tagesson T, Fensholt R (2018) Snow cover and snow albedo changes in the central Andes of Chile and Argentina from daily MODIS observations (2000-2016). Remote Sens Environ 209(February):240-252. https://doi.org/10.1016/j.rse.2018.02.072

23. Cereceda-Balic F, Vidal V, Moosmüller H, Lapuerta M (2018) Reduction of snow albedo from vehicle emissions at Portillo, Chile. Cold Reg Sci Technol 146:43-52. https://doi. org/10.1016/J.COLDREGIONS.2017.11.008

24. Delbart N, Dunesme S, Lavie E, Madelin M, Goma R (2015) Remote sensing of Andean mountain snow cover to forecast water discharge of Cuyo rivers. Journal of Alpine Research. https://doi.org/10.4000/rga.2903

25. Cereceda-Balic F, Palomo-Marín MR, Bernalte E, Vidal V, Christie J, Fadic $X$ et al (2012) Impact of Santiago de Chile urban atmospheric pollution on anthropogenic trace elements enrichment in snow precipitation at Cerro Colorado, Central Andes. Atmos Environ 47:51-57. https://doi.org/10.1016/J. ATMOSENV.2011.11.045

26. Bolaño-Ortiz TR, Allende DG, Puliafito SE, Pascual-Flores RM, Ruggeri MF (2017) Potential deposition of atmospheric aerosols on the snow and albedo reduction in the Mendoza river basin, Argentina. In: 5th iLEAPS science conference abstracts, Oxford, UK. https://doi.org/10.13140/rg.2.2.20370.09924

27. Bolaño-Ortiz TR, Ruggeri MF, Pascual-Flores RM, Allende DG, Lakkis SG, Puliafito SE (2018) Relationship between anthropic pollution in the Santiago Metropolitan Region and the decrease of snow albedo on the Maipo river basin, Chile. In: 2018 joint 14th iCACGP quadrennial symposium/15th IGAC science conference, Takamatsu, Japan. https://doi. org/10.13140/rg.2.2.16385.51043

28. Klein AG, Stroeve J (2002) Development and validation of a snow Albedo algorithm for the MODIS instrument. Ann Glaciol 34:45-52. https://doi.org/10.3189/172756402781817662 
29. Hall DK, Riggs GA, Salomonson VV, DiGirolamo NE, Bayr KJ (2002) MODIS snow-cover products. Remote Sens Environ 83(1-2):181-194

30. Riggs GA, Hall DK, Salomonson VV (2006) MODIS snow products. User guide to collection 5. https://modis-snowice.gsfc.nasa.gov/ uploads/sug_c5.pdf. Accessed 25 Nov 2018

31. Wan Z, Li Z-L (1997) A physics-based algorithm for retrieving land-surface emissivity and temperature from EOS/MODIS data. IEEE Trans Geosci Remote Sens 35(4):980-996. https://doi. org/10.1109/36.602541

32. Klein AG, Barnett AC (2003) Validation of daily MODIS snow cover maps of the Upper Rio Grande River Basin for the 20002001 snow year. Remote Sens Environ 86(2):162-176. https:// doi.org/10.1016/s0034-4257(03)00097-x

33. Levy R, Hsu C (2015) MODIS atmosphere L2 aerosol product. NASA MODIS adaptive processing system. Goddard Space Flight Center, Terra, Greenbelt. https://doi.org/10.5067/MODIS/MOD08 D3.006

34. Skiles SMK, Flanner M, Cook JM, Dumont M, Painter TH (2018) Radiative forcing by light-absorbing particles in snow. Nature Climate Change 8(11):964-971. https://doi.org/10.1038/s4155 8-018-0296-5

35. Huffman GJ, Bolvin DT, Nelkin EJ, Wolff DB, Adler RF, Gu G et al (2007) The TRMM multi-satellite precipitation analysis (TMPA): quasi-global, multiyear, combined-sensor precipitation estimates at fine scales. J Hydrometeorol. https://doi.org/10.1175/ jhm560.1

36. Huffman G, Bolvin D (2007) TRMM and other data precipitation data set documentation. https://doi.org/10.1162/leon_r_00463

37. Adler RF, Huffman GJ, Bolvin DT (2000) Tropical rainfall distributions determined using TRMM combined with other satellite and rain gauge information. J Appl Meteorol. https://doi. org/10.1175/1520-0450(2001)040\%3c2007:trddut\%3e2.0.co;2

38. Hong Y, Alder R, Huffman G (2006) Evaluation of the potential of NASA multi-satellite precipitation analysis in global landslide hazard assessment. Geophys Res Lett. https://doi. org/10.1029/2006gl028010

39. Seemann SW, Borbas EE, Li J, Menzel WP, Gumley LE (2006) MODIS atmospheric profile retrieval algorithm theoretical basis document. Cooperative Institute for Meteorological Satellite Studies, University of Wisconsin-Madison, Madison, WI, Version 6. http://citeseerx.ist.psu.edu/viewdoc/download ?doi=10.1.1.385.7746\&rep=rep1\&type=pdf. Accessed $19 \mathrm{Nov}$ 2018

40. Rolph G, Stein A, Stunder B (2017) Real-time environmental applications and display system: READY. Environ Model Softw 95:210-228. https://doi.org/10.1016/j.envsoft.2017.06.025

41. Stein AF, Draxler RR, Rolph GD, Stunder BJB, Cohen MD, Ngan $F$ (2015) NOAA's HYSPLIT atmospheric transport and dispersion modeling system. Bull Am Meteor Soc 96(12):2059-2077. https://doi.org/10.1175/BAMS-D-14-00110.1

42. Flanner MG, Zender CS (2006) Linking snowpack microphysics and Albedo evolution. J Geophys Res 111:D12208. https://doi. org/10.1029/2005jd006834

43. Grell GA, Peckham SE, Schmitz R, McKeen SA, Frost G, Skamarock WC, Eder B (2005) Fully coupled "online" chemistry within the WRF model. Atmos Environ 39(37):6957-6975. https://doi. org/10.1016/J.ATMOSENV.2005.04.027

44. Flanner MG, Zender CS, Randerson JT, Rasch PJ (2007) Presentday climate forcing and response from black carbon in snow. J Geophys Res 112(D11):D11202. https://doi.org/10.1029/2006J D008003

45. Xu R, Tie X, Li G, Zhao S, Cao J, Feng T, Long X (2018) Effect of biomass burning on black carbon $(B C)$ in South Asia and Tibetan Plateau: the analysis of WRF-Chem modeling. Sci
Total Environ 645:901-912. https://doi.org/10.1016/j.scito tenv.2018.07.165

46. Grell GA, Peckham SE, Schmitz R, McKeen SA, Frost G, Skamarock WC, Eder B (2005) Fully coupled "online" chemistry within the WRF model. Atmos Environ 39(37):6957-6975. https://doi. org/10.1016/j.atmosenv.2005.04.027

47. Puliafito SE, Allende DG, Mulena CG, Cremades P, Lakkis SG (2015) Evaluation of the WRF model configuration for Zonda wind events in a complex terrain. Atmos Res 166:24-32. https ://doi.org/10.1016/j.atmosres.2015.06.011

48. Mulena GC, Allende DG, Puliafito SE, Lakkis SG, Cremades PG, Ulke AG (2016) Examining the influence of meteorological simulations forced by different initial and boundary conditions in volcanic ash dispersion modelling. Atmos Res 176177:29-42. https://doi.org/10.1016/j.atmosres.2016.02.009

49. Cremades PG, Fernández RP, Allende DG, Mulena GC, Puliafito SE (2017) High resolution satellite derived erodibility factors for WRF/Chem windblown dust simulations in Argentina. Atmosfera 30(1):11-25. https://doi.org/10.20937/ ATM.2017.30.01.02

50. Morata $D$, Polvé $M$, Valdés $A$, Belmar $M$, Dinator $M I$, Silva $M$ et al (2008) Characterisation of aerosol from Santiago, Chile: an integrated PIXE-SEM-EDX study. Environ Geol 56(1):81-95. https://doi.org/10.1007/s00254-007-1141-8

51. Keegan KM, Albert MR, McConnell JR, Baker I (2014) Climate change and forest fires synergistically drive widespread melt events of the Greenland Ice Sheet. Proc Natl Acad Sci. https:// doi.org/10.1073/pnas.1405397111

52. Zhang Y, Kang S, Cong Z, Schmale J, Sprenger M, Li C et al (2017) Light-absorbing impurities enhance glacier albedo reduction in the southeastern Tibetan plateau. J Geophys Res. https://doi.org/10.1002/2016jd026397

53. Markowicz KM, Lisok J, Xian P (2017) Simulations of the effect of intensive biomass burning in July 2015 on Arctic radiative budget. Atmos Environ 171:248-260. https://doi. org/10.1016/j.atmosenv.2017.10.015

54. Liou KN, Takano Y, Yang P (2011) Light absorption and scattering by aggregates: application to black carbon and snow grains. J Quant Spectrosc Radiat Transfer 112(10):1581-1594. https://doi.org/10.1016/j.jqsrt.2011.03.007

55. Garreaud RD, Vuille M, Compagnucci R, Marengo J (2009) Present-day South American climate. Palaeogeogr Palaeoclimatol Palaeoecol 281(3-4):180-195. https://doi.org/10.1016/j.palae o.2007.10.032

56. Cornwell E, Molotch NP, McPhee J (2016) Spatio-temporal variability of snow water equivalent in the extra-tropical Andes Cordillera from distributed energy balance modeling and remotely sensed snow cover. Hydrol Earth Syst Sci 20(1):411430. https://doi.org/10.5194/hess-20-411-2016

57. Mernild SH, Liston GE, Hiemstra C, Beckerman AP, Yde JC, McPhee J (2017) The Andes Cordillera. Part IV: spatio-temporal freshwater run-off distribution to adjacent seas (1979-2014). Int J Climatol 37(7):3175-3196. https://doi.org/10.1002/ joc. 4922

58. Fischer EV, Hsu NC, Jaffe DA, Jeong MJ, Gong SL (2009) A decade of dust: asian dust and springtime aerosol load in the U.S. Pacific Northwest. Geophys Res Lett 36(3):1-5. https:// doi.org/10.1029/2008gl036467

59. Li X, Kang S, He X, Qu B, Tripathee L, Jing Z et al (2017) Lightabsorbing impurities accelerate glacier melt in the Central Tibetan Plateau. Sci Total Environ. https://doi.org/10.1016/j. scitotenv.2017.02.169

60. Zhang H, Wang Z, Wang Z, Liu Q, Gong S, Zhang X et al (2012) Simulation of direct radiative forcing of aerosols and their effects on East Asian climate using an interactive 
AGCM-aerosol coupled system. Clim Dyn. https://doi. org/10.1007/s00382-011-1131-0

61. Gallardo L, Escribano J, Dawidowski L, Rojas N, de Fátima Andrade M, Osses M (2012) Evaluation of vehicle emission inventories for carbon monoxide and nitrogen oxides for Bogotá, Buenos Aires, Santiago, and São Paulo. Atmos Environ 47:12-19. https://doi.org/10.1016/j.atmosenv.2011.11.051

62. Mena-Carrasco M, Oliva E, Saide P, Spak SN, de la Maza C, Osses $M$ et al (2012) Estimating the health benefits from natural gas use in transport and heating in Santiago, Chile. Sci Total Environ 429:257-265. https://doi.org/10.1016/J.SCITO TENV.2012.04.037

63. Vásquez L, Iriarte A, Almeida M, Villalobos P (2015) Evaluation of greenhouse gas emissions and proposals for their reduction at a university campus in Chile. J Clean Prod 108:924-930. https://doi.org/10.1016/J.JCLEPRO.2015.06.073

64. Jorquera $\mathrm{H}$ (2002) Air quality at Santiago, Chile: a box modeling approach-I Carbon monoxide, nitrogen oxides and sulfur dioxide. Atmos Environ 36(2):315-330. https://doi. org/10.1016/s1352-2310(01)00417-4

65. Osses M, Urrutia CM (2002) Hot emission model for mobile sources: application to the metropolitan region of the City of Santiago, Chile. J Air Waste Manag Assoc 52(2):167-174. https ://doi.org/10.1080/10473289.2002.10470774
66. Eskeland GS (1997) Air pollution requires multipollutant analysis: the case of Santiago, Chile. Am J Agr Econ 79(5):16361641. https://doi.org/10.2307/1244395

67. Masiokas MH, Villalba R, Luckman BH, Le Quesne C, Aravena JC (2006) Snowpack variations in the Central Andes of Argentina and Chile, 1951-2005: large-scale atmospheric influences and implications for water resources in the region. J Clim 19(24):6334-6352. https://doi.org/10.1175/JCLI3969.1

68. Masiokas MH, Christie DA, Le Quesne C, Pitte P, Ruiz L, Villalba $R$ et al (2016) Reconstructing the annual mass balance of the Echaurren Norte glacier (Central Andes, $33.5^{\circ} \mathrm{S}$ ) using local and regional hydroclimatic data. Cryosphere 10(2):927-940. https://doi.org/10.5194/tc-10-927-2016

69. Meza FJ, Wilks DS, Gurovich L, Bambach N (2012) Impacts of climate change on irrigated agriculture in the Maipo Basin, Chile: reliability of water rights and changes in the demand for irrigation. Journal of Water Resources Planning and Management 138(5):421-430. https://doi.org/10.1061/(ASCE)WR.19435452.0000216

Publisher's Note Springer Nature remains neutral with regard to jurisdictional claims in published maps and institutional affiliations. 